\title{
Economic value estimation of mangrove ecosystems in Indonesia
}

\begin{abstract}
Mangroves are highly productive ecosystem with various important social, economic and environmental functions. In Indonesia, mangrove ecosystem is one of the threatened resources in the coastal zone, and the mangroves have been under intense pressure from competing resources use. In many parts of Indonesia, the social economic values for mangrove ecosystem are varied depending on local specific of the ecosystem. The direct use value of mangrove ecosystem has been tapped for wood, charcoal, tannin, construction material, household equipment, medicines, fish, shrimp, crab, vegetable and raw material for pulp and paper industries. The indirect use value of mangrove ecosystem is in the from of vital ecological functions including control coastal erosion, prevention of salt interaction, stabilization of sediment, procession of adjacent coral reef from suspend solid, protection of coastal land from storm, natural purification of coastal water from pollution, supply of organic detritus and nutrients to adjacent coastal water, and the prevision of feeding, nursery and breeding areas for fish, crustacean and wild life. Using total economic valuation methodology, the economic value of mangrove resource is estimated ranging from US \$3,624.98 - US $\$ 26,734.61$ per ha per year.
\end{abstract}

Volume 2 Issue I - 2018

\author{
Achmad Rizal, Asep Sahidin, Heti Herawati \\ Faculty of Fishery and Marine Science, Universitas Padjadjaran, \\ Indonesia
}

\begin{abstract}
Correspondence: Achmad Rizal, Socio-Economic Studies Center for Fisheries, Faculty of Fishery and Marine Science, Universitas Padjadjaran, Jl Raya Bandung Sumedang Km 21, Jatinangor 45363, West Java, Indonesia, Tel +62-22-87701519, Email achmad.rizal@unpad.ac.id
\end{abstract}

Received: January 19, 2018 | Published: February 21, 2018

\section{Introduction}

Indonesia has a huge potential of mangrove resources. In 2010 , the mangrove area was 5,209,543.16hectares and the area was decline rapidly to $2,496,185$ hectares in 2016. This figure shows depletion and degradation of mangrove ecosystem and therefore, the capacities to supply human needs are decline because of the intense pressure from many activities in the development of coastal zone. The data above noted that development activities have threatened the sustainable capacity of the mangrove ecosystem in supporting future development in Indonesia. Mangroves provide a wide range of ecosystem services, including nutrient cycling, soil formation, wood production, fish spawning grounds, ecotourism and carbon (C) storage. Indonesia has a huge potential of mangrove resources. The biological resources of the mangrove ecosystem which are believed to be highly productive are not only able to provide various valuable forest products, but also maintain estuarine water quality as a habitat for many commercially important species of fish and prawns. For tropical countries, the mangrove is one of the important natural resources for the development sector in order to enhance human welfare through resource exploitation and environmental stability. Therefore, an adequate balance must be sought between the environmental benefits of the marginal mangroves and the productive role of these ecosystems on a sustained management basis. ${ }^{1}$

Mangroves are forest ecosystems formed by halophytic, woody, seed-bearing plants which range in size from tall trees to small shrubs. They have the ability to grow along sheltered, intertidal coastlines on sediments that are saline, often aerobic and sometime acidic. Mangroves are highly productive ecosystems with various important economic, social and environmental functions. Daniel etal. ${ }^{1}$ mentioned that mangrove ecosystems in Indonesia has the highest biodiversity in the world, i.e. 89 species; 35 of them are trees, and the rest are in form of terma ( 5 species), perdu ( 9 species), liana ( 9 species), epiphyte (29 species) and parasite (2 species). Dahuri et al. ${ }^{2}$ noted some mangrove species which usually found in coastal area of Indonesia are bakau (Rhizopora spp), api-api (Avicennia spp), pedada (Sonneratia spp), tanjang (Brugeira spp), nyirih (Xylocarpus spp), tengar (Ceriops spp) and buta-buta (Exoecaria spp).

In Indonesia, the direct use value of mangroves has been tapped for wood, charcoal, tannins, construction materials, household equipment, medicines and raw material for pulp and paper industries. The indirect use value of mangroves ecosystem is in the form of vital ecological functions including control of coastal erosion, stabilization of sediment, protection of adjacent coral reefs from suspended solids, protection of coastal land uses from storms, prevention of salt intrusion, natural purification of coastal water from pollution, supply of organic detritus and nutrients to adjacent coastal waters, and the provision of feeding, nursery and breeding areas for economically important fish, crustaceans and wild life. ${ }^{3}$

The conversion of coastal wetlands to other uses affects habitats of critically important valuable marine species. Convincing evidence exist that mangroves serve as critically important habitat for shrimp in the post larvae and juvenile stages of their life cycle. ${ }^{4}$ Many scientists are arguing that a long term value of mangrove habitats is greater than its value for any other use, including coastal aquaculture. Therefore, careful management of this resource provides numerous benefits to a variety of users. Government provides maximizing producers and utility maximizing consumers in traditional markets should allocate scarce coastal resources and environmental uses in an economically efficient manner. Coastal zone management must address resource allocation in an economically efficient manner by providing information on value of coastal resources. The information from resource valuation will help guide decision makers to more objectively consider management options in allocating scarce coastal resources efficiently.

\section{Valuation methods}

There are basically two broad approaches to valuation, each comprising a number of techniques. These are the direct and indirect approaches. The direct approach looks at techniques which attempt to 
elicit preferences directly through the use of survey and experimental techniques, such as contingent valuation and contingent ranking methods. People are asked directly to state or reveal their strength of preference for a proposed resource. In contrast, the indirect approach is a technique which seeks to elicit preferences from actual, observed market-based information.

Most of studies have been done in Indonesia using total economic value. The total economic value of a resource can be disaggregated in two components which are use value (UV) and non use value (NUV). Use value includes direct use value (DUV), indirect use value (IUV) and option value (OV). Nonuse value, on the other hand, has proved to be both difficult to define and measure. Nonuse value can be subdivided into existence value (XV) which measures willingness to pay for some moral, altruistic or other reason and unrelated to use or option value and bequest value (BV) which measure an individual's willingness to pay to ensure that his/her heirs will use the resource in the future. The total economic value can be expressed by:

\section{$\mathrm{TEV}=\mathrm{UV}+\mathrm{NUV}=(\mathrm{DUV}+\mathrm{IUV}+\mathrm{OV})+(\mathrm{XV}+\mathrm{BV})$}

The economic valuation of a coastal resource can be carried out through two stages:

\section{Identification stage}

This is an important stage to know the benefits and functions of a coastal resource, especially the function in relationship with the other components in an ecosystem. The identified benefits include:

Direct use value (DUV): This is defined as use which is directly obtained from using a mangrove ecosystem, such as the use of mangrove for firewood, timber and fishing, etc. The total direct use from a mangrove ecosystem can be formulated in a simple equation: Direct use (mangrove $)=$ Firewood use + timber use + fishing, etc .

Indirect use value (IUV): An indirect use is defined as use which is indirectly derived from a mangrove ecosystem such as spawning ground, nursery ground, feeding ground and beach protection from waves.

Option value (OV): The concept of option value can be interpreted as the potential future direct and indirect uses of a natural system. If the uncertainty regarding future use is measurable in the form of probability for a certain outcome, the option value can be interpreted as the risk premium paid to avoid the outcome of reversible destruction. In other words, the individual is willing to pay an amount in addition to the actual price today in order to keep the use option for later. Therefore, total use value can be defined as the sum of current total direct and indirect use values and this risk premium.

Existence value (EV): An existence value is interpreted as a value humans gain from simply knowing that an ecosystem or species exists, independent of weather an individual uses it or not. The existence value of an ecosystem can be approached by using the contingent valuation method through a survey of selected respondents.

Bequest value: A bequest value is related to preserving the natural heritage for the coming generations. Its value is derived today from knowing that the natural heritage will exist and will be used by the future generation.

Based on the above, the total economic value (TEV) is a sum of direct use value (DUV), indirect use value (IUV), option value (OV), existence value (EV) and bequest value (BV).

\section{Quantification stage}

A quantification stage is the accounting of the total use and function of an ecosystem in monetary terms. There are a lot of quantification methods which are often used, some of which are:

A. Market price: The market price approach is used to account for a marketable component of a natural system, such as firewood and fish from a mangrove forest. The approach is used to value a direct use.

B. Indirect price: An indirect price can be used to account for the non-marketable component of a natural system. This method is very suitable to evaluate a physical and biological use.

C. Contingent valuation method: Contingent valuation method is a very popular approach which is most used in valuating an environmental component, especially for a non-marketable one. In general, this method is carried out through a survey by asking the selected respondents about the existence of a certain component of a natural system.

\section{Selecting management options}

In order to select the best management option for achieving sustainable resources management, some studies has been done by Rizal et al. ${ }^{5}$ and Rizal. ${ }^{6}$ There studies used Cost-benefit analysis in comparing each management option. Cost-benefit analysis aimed at assisting the decision maker to make a decision which is consistent with efficiency in the allocation of resources in certain area. Benefit and cost of proposed management option in the mangrove ecosystem were calculated as follows.

$$
\text { Net Present Value (NPV) }=\sum_{t=i}^{n}\left(B_{t}-C_{t}\right) /(1+r)^{t}
$$

Where:

$\mathrm{Bt}=$ Benefit from using mangrove ecosystem

$\mathrm{Ct}=$ Cost of using mangrove ecosystem

$\mathrm{t}=$ Time horizon (year)

$\mathrm{r}=$ Discount rate $(\%)$

The selection the best management option was based on the highest value of NPV.

\section{Social economic value of mangrove ecosystems}

Social value of mangrove ecosystem can be expressed by how many man/month utilized the resource, Rizal [6] estimated. 38 manmonth per hectar per year involve in tapping mangrove ecosystem. Economic value of mangrove ecosystem can be viewed from its functions which are social, ecological, physical and chemical aspects. This functions are classified to their uses, namely direct use value (DUV), indirect use value (IUV), option value (OV) and existence value $(\mathrm{EV})$. The benefit of mangrove ecosystem per hectare per year in Indonesia can be value as follows

Direct use value: There are 26 productive identified uses for the mangrove ecosystem in Indonesia varying from timber, fire wood, fisheries and other uses. The economic value of this direct use value ranging from US $\$ 19.42$ to US $\$ 1,687.24$.

Indirect use value: Six indirect use values are considered, varying from food source to storm protection with economic value ranging from US $\$ 637.93$ to US $\$ 24,000.53$. 
Option value: Biodiversity has been selected to refer the different types of biological diversity habitats or traits which exist in any given system. The biodiversity value is US $\$ 15.00$.

Existence value: Existence value is interpreted as value humans gain from simply knowing that an ecosystem or species exists, independent of whether an individual uses it or not. By using the contingent valuation method, the communities valuate the mangrove resources US $\$ 560.00$ to US $\$ 2,516.40$.

The cost of using the mangrove are ranging from US $\$ 12.71$ to US $\$ 975.76$ per hectare therefore the total economic value of mangrove ecosystem is ranging from US $\$ 3.624 .98$ to US $\$ 26,734.61$ per hectare per year.

\section{Management options for sustainable mangrove ecosystem}

In order to select the best management option for achieving sustainable Mangrove Ecosystem management, some studies has been done by Ruitenbeek, ${ }^{7}$ Oglethorpe \& Miliadou, ${ }^{8}$ and Rizal et al. ${ }^{5}$ There studies used Cost-benefit analysis in comparing each management option. Cost-benefit analysis aimed at assisting the decision maker to make a decision which is consistent with efficiency in the allocation of resources in certain area. The selection the best management option was based on the highest value of NPV. The procedure for selecting management options will often rely on some judgments about technical and economic feasibility. Using scenarios, the mangrove management options selected are sylvofisheries-tilapia aquaculture, sylvofisheries-shrimp aquaculture and sustainable forest management. Using the benefit-cost analysis framework, the analysis showed that by allocating $80 \%$ for mangroves and $20 \%$ for aquaculture: tilapia aquaculture resulted in lower NPV (US \$10,347.6) compared to sustainable mangrove forest management (US \$11,043.2). The management option for sylvofisheries-shrimp aquaculture resulted in a higher NPV (US \$15,195.2) compared to sustainable mangrove forests. ${ }^{6}$

\section{Conclusion}

A longstanding theoretical paradigm suggests that mangrove diversity is important because it enhances the productivity and stability of ecosystems. ${ }^{9}$ The awareness of the uses and functions of mangrove can be viewed by knowing its functions for enhancing the productivity and stability of coastal ecosystems. At first sight, the resulting monetary value estimates seem to give unequivocal support to the belief that mangrove ecosystem has a significant, positive social value. Mangrove ecosystem plays an important role for the livelihood of small-scale fishermen whose life dependent upon fishing and marine related activities around the coastal. However, given a high potential economic value that could have been generated from other activities and the need to protect the mangrove forest from over exploitation, there should be a tradeoff between protecting the right of stakeholder to utilize the mangrove ecosystem and allowing the government to establish mangrove ecosystem management strategy.

The awareness of the uses and functions of mangrove ecosystems can be viewed by knowing its social economic, ecological, physical and chemical functions. Therefore, it is important to value the resources before deciding a development program, since in addition of the market value, the resource has attributed to many uses and function which is not marketed. Management of mangrove ecosystems should address that the resources is not only valued interm productive capacity but the total functions of the ecosystem. The incorporation of market and non market value of the resource in selecting the best management options will result to an efficient allocation of resource and the sustainability of the mangrove ecosystems. ${ }^{10,11}$

\section{Acknowledgements}

We would like to thank Faculty of Fishery and Marine Science, Universitas Padjadjaran, Indonesia for making this research possible. We also thank Ministry of Marine and Fisheries of Indonesia Republic for their assistance in providing much needed information.

\section{Conflict of interest}

Author declares there is no conflict of interest in publishing the article.

\section{References}

1. Daniel CD, Kauffman JB, Murdiyarso D, et al. Mangroves among the most carbon-rich forests in the tropics. Nature Geosciences Letters. 2011;4:293-267.

2. Dahuri R, Nikijuluw VP, Manadyanto L, et al. Development of Wisdom Study. Environmental Economics, PPLH-IPB, Bogor, Indonesia; 1995.

3. Rizal A, Lantun PD. Using economic values to evaluate management options for fish biodiversity in the Sikakap Strait, Indonesia. Biodiversitas Journal. 2017;18(2):586-592.

4. Bailey C. The social consequences of tropical shrimp marinculture development. Ocean shoreline Manage. 1988;11(1):31-44.

5. Rizal A, Purwanto AB, Pawitno. Economic Valuation of Coastal and Marine Resources in Aceh. Cooperation between State Ministry of Environment and PKSPL-IPB, Bogor, Indonesia; 2001.

6. Rizal A. Economic Valuation of Coastal and Marine Resource of Mentawai island. Faculty of fishery and Marine Science. Padjadjaran University, Jatinangor, Indonesia; 2016.

7. Ruitenbeek HJ. Mangrove management: an economic analysis of management options with a focus on Bintuni Bay, Irian Jaya. Environmental Management Development in Indonesia Project (EMDI), Indonesia; 1992.

8. Oglethorpe DR, Miliadou D. Economic Valuation of the Non-use Attributes of a Wetland: A Case-Study for Lake Kerkini. Journal of Environmental Planning and Management. 2000;43(6):755-767.

9. Odum HT. Bird populations of the Highlands Plateau in relation to plant succession and avian invasion. Ecology. 1950;31(4):587-605.

10. Barton DN. Economic factors and valuation of tropical coastal resources. Centre for Studies of Environment and Resources, University of Bergen, Norway; 1994.

11. Munasinghe M, Lutz E. Environmental economics and valuation in Development in decision making. Environmental Working paper 51, World Bank, Washington, USA; 1992 